\title{
溶銑脱りん速度に及ぼす攪找力, 酸素供給速度の影響
}

\author{
務川 進*・水上 義正*
}

The Effect of Stirring Energy and the Rate of Oxygen Supply

on the Rate of Hot Metal Dephosphorization

Susumu Mukawa and Yoshimasa Mızuкamı

Synopsis : Study was made on the desiliconization and dephosphorization reaction kinetics at various size equipments. Coupled reaction model was employed to analyse the rate determining step of desiliconization and dephosphorization reaction.

By model calculations, the rate determining step of desiliconization reaction is the mass transfer process in the hot metal and mass transfer both in hot metal and slag for dephosphorization reaction. The mass transfer coefficient in hot metal $\mathrm{k}_{\mathrm{m}}$ proportionally increased with 0.7 power of parameter $\varepsilon / \mathrm{d}_{\mathrm{c}}{ }^{2}$, independently on the equipment size, where, $\varepsilon$, $\mathrm{d}_{\mathrm{c}}$ is the stirring energy of hot metal and the diameter of vessel, respectively.

Apparent rate constant of dephosphorization $\mathrm{kp}^{\prime}=\ln \left([\% \mathrm{P}]_{\mathrm{i}} /[\% \mathrm{P}]_{\mathrm{f}}\right) / \mathrm{t}_{\mathrm{f}}$ increased from $0.10 \mathrm{~min}^{-1}$ to $0.33 \mathrm{~min}^{-1}$, when stirring energy $\varepsilon^{\prime}$ and the rate of oxygen supply $\mathrm{V}_{\mathrm{O}_{2}}$ was increased under the optimum relationship between $\varepsilon^{\prime}$ and $\mathrm{V}_{\mathrm{O}_{2}}$ which is predicted by the model calculations, where $[\% \mathrm{P}]_{\mathrm{i}}$ and $[\% \mathrm{P}]_{\mathrm{f}}$ is initial and final phosphorus content and $t_{f}$, refining time. This optimum relationship was expressed as the empirical equation, $\varepsilon^{\prime}=1.51 \mathrm{~V}_{\mathrm{o}_{2}}{ }^{2}+3.31 \mathrm{~V}_{\mathrm{o}_{2}} \mathrm{under}$ the condition of this study.

Key words : hot metal pretreatment; dephosphorization of hot metal ; desiliconization of hot metal ; coupled reaction model ; reaction kinetics; rate of dephosphorization; mass transfer coefficient; rate determining step.

\section{1. 緒言}

浴銑了・借処理技術は监に低温を利川した效摔的な脱りん を行って生们庅原监位を低減するだけでなく，転灯の生应

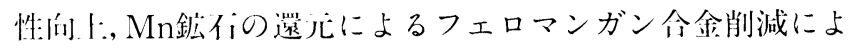
る精鍊コス卜低減に大きな谷少をし得ることが明らかとな つてきた1)。それいえ，近作，活級銅のみならずすべての溶

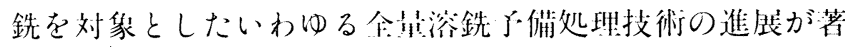

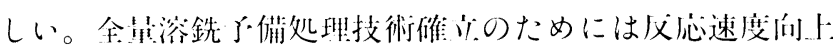
による牛涟性の確保が重装な課題である。

操業の妟適化を行うトでは文忍速度淪的な検刺を行い最 適な覺㧣条俳，酸系供給速度を㺫らかにする必要がある。

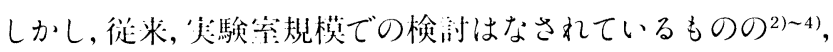
実機規模での十分な検副はなされていない。

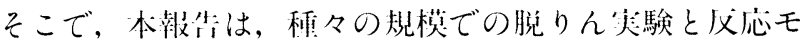
デル解析によって，プロセスの最邀化について検郭したの で報售する。

\section{2. 実験方法}

\section{$2 \cdot 1 \quad 0.5 \mathrm{~kg}$ 規模脱りん実験}

溶銑脱りん文心の律速段階について検討することを目的 とし，0.5kg規模での浴銑脱りん㶤験を行った。
あらかじめ黒鉜るつぼで電解鉄を溶解し一H凝阁させて 作成した銑鉄 $0.5 \mathrm{~kg}$ を抵抗加熱炉内で内径 $0.04 \mathrm{~m}$ のマグネシ アるつぼ内に溶解後, 合金を添加してTable 1 の日標值に調 整し，600～1200s保持した。次にTable 2 に示す脱りんフラ ックスを上方から添加して脱りん処理を開始した。脱りん フラックスは 100 mesh以下の $\mathrm{CaO}, \mathrm{Fe}_{2} \mathrm{O}_{3}, \mathrm{SiO}_{2}, \mathrm{CaF}_{2}$ 粉 末試薬をあらかじめ機械的に混合したものであり, $\mathrm{CaO}$ 添 加量は最終スラグの $\mathrm{CaO} / \mathrm{SiO}_{2}$ 重量パーセント比(以下塩基。

Table 1. Initial composition of hot metal for laboratory scale experiments (mass \%).

\begin{tabular}{cccccc}
\hline Scale & $\mathrm{C}$ & $\mathrm{Si}$ & $\mathrm{Mn}$ & $\mathrm{P}$ & $\mathrm{S}$ \\
\hline \multirow{2}{*}{$0.5 \mathrm{~kg}$} & 4.5 & 0.0 & 0.10 & 0.10 & 0.04 \\
& 4.5 & 0.3 & 0.10 & 0.10 & 0.04 \\
\hline \multirow{2}{*}{$170 \mathrm{~kg}$} & 4.5 & 0.3 & 0.10 & 0.10 & 0.02 \\
& 4.5 & 0.8 & 0.10 & 0.10 & 0.02 \\
\hline
\end{tabular}

Table 2. Composition and wight of fluxes used at laboratory scale experiments.

\begin{tabular}{cccrrrrrr}
\hline \multirow{2}{*}{ Scale } & \multicolumn{7}{c}{$\begin{array}{c}\text { Aimed } \\
{[\% \mathrm{Si}]}\end{array}$} & \multicolumn{6}{c}{ Flux composition(mass\%) } & Total & Aimed & Run \\
& $\mathrm{CaO}$ & $\mathrm{SiO}_{2}$ & $\mathrm{Fe}_{2} \mathrm{O}_{3}$ & $\mathrm{CaF}_{2}$ & amount(kg) & basicity & No. \\
\hline \multirow{2}{*}{$0.5 \mathrm{~kg}$} & 0.0 & 27.0 & 13.5 & 48.5 & 11.0 & 0.0438 & 1.93 & $1-1$ \\
& 0.3 & 20.5 & 3.2 & 72.2 & 4.1 & 0.0487 & 1.76 & $1-2$ \\
\hline \multirow{2}{*}{$170 \mathrm{~kg}$} & 0.8 & 17.0 & - & 76.2 & 6.8 & 10.0 & 0.6 & $2-1,2,3$ \\
& 0.3 & 20.5 & - & 78.6 & 0.9 & 10.7 & 2.0 & $2-4$ \\
\hline
\end{tabular}


Table 3. Experimental condition of $0.5 \mathrm{~kg}$ scale experiments.

\begin{tabular}{c|c}
\hline Temperature & $1350^{\circ} \mathrm{C}$ \\
Weight of hot metal & $0.50 \mathrm{~kg}$ \\
Atmosphere & $\mathrm{Ar}$ \\
Crucible & $\mathrm{MgO}, 0.040 \mathrm{~m} \phi$ \\
\hline
\end{tabular}

度と略す)が1.7〜2.0となるようにした。溶銑組成の経時変 化を調べるため，不英サンプラーを用いて溶銑を吸い.ド 採取し分析に供した。2400s経過後，スラグを鉄製棒に付着 させて採取し，分析を行った。実験中，炉内にArガスを $1.7 \times$ $10^{-4} \mathrm{Nm}^{3} / \mathrm{s}$ の流量で流した。その他の実験条件をTable 3 に 示寸。

\section{$2 \cdot 2170 \mathrm{~kg}$ 規模実験}

物質移動係数に及ぼすガス攪汼の影響を明らかとするこ とを目的に $170 \mathrm{~kg}$ 規模での脱りん笑験を行った。实験はFig. 1 に示寸高周波溶解炉を用いて行った。笑験水準はTable 2 に示すように，初期珪素濃度を $0.8 \%$ の場合と $0.3 \%$ の埸合 の 2 水準とし,珪素濃度 $0.8 \%$ の笑験では吹き込みAr星をか えて攪挥力の異なる実験も行った。銑鉄 $170 \mathrm{~kg}$ を内徍 $0.33 \mathrm{~m}$ のるつぼ内で溶解し $1350^{\circ} \mathrm{C}$ 一定に保ちながら 120 sから 180 s保 持した後珪素を添加し，りん0.1\%，硫黄0.04\%となるよう 合金添加を行った。脱りん処理は上方からアルミナ製ラン スを表面から0.15mの深さに浸漬し Arガス攪汼を行った。 フラックスは初期に $120 \mathrm{~s} こ と に 10$ 回に分割添加した。反応時 間は3000sとし，溶銑組成の経時変化を調査するため，所定 の時間間隔で溶銑試料を採取し分析に供した。また，3000 s経過後，スラグを鉄製スプーンで汲み上げ採取し，分析を 行った。その他の条件はTable 4 に示す。

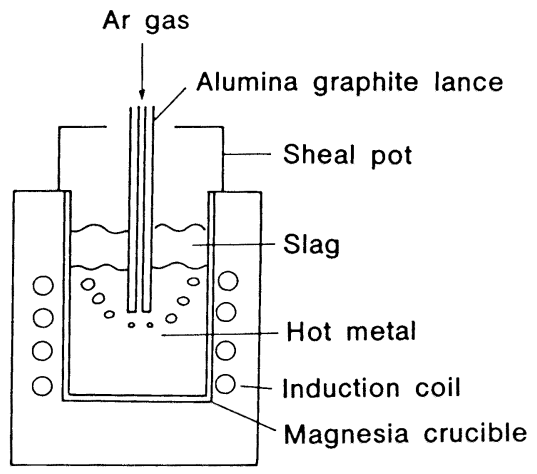

Fig. 1. Experimental apparatus for $170 \mathrm{~kg}$ scale experiments.

Table 4. Experimental condition of $170 \mathrm{~kg}$ scale experiments.

\begin{tabular}{c|c}
\hline Temperature & $1350^{\circ} \mathrm{C}$ \\
Weight of hot metal & $170 \mathrm{~g}$ \\
Injection gas & $\mathrm{Ar}$ \\
Gas flow rate & $0.83 \sim 5.0 \times 10^{-4} \mathrm{Nm}^{3} / \mathrm{s}$ \\
Crucible & $\mathrm{MgO}, 0.33 \mathrm{~m} \phi$ \\
\hline
\end{tabular}

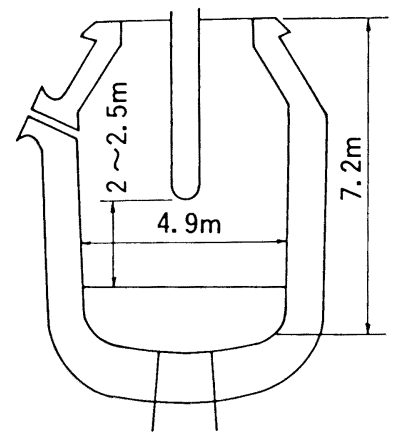

Fig. 2. Schematic view of the reactor for 110 t scale experiments.

Table 5. Experimental condition of $110 \mathrm{t}$ scale experiments.

\begin{tabular}{c|c}
\hline Temperature & $1275 \mathrm{C} \sim 1350 \mathrm{C}$ \\
Weight of hot metal & $110 \times 10)^{3} \mathrm{~kg}$ \\
Injection gas & $\mathrm{N}_{2},\left(0.11 \mathrm{Nm}^{3} / \mathrm{s}\right.$ \\
Injection powder & $\mathrm{CaCO}_{3}(0.35 \sim 2.87 \mathrm{~kg} / \mathrm{s}$ \\
Top blow lance & $\mathrm{CaO} 1.01 \sim 1.65 \mathrm{~kg} / \mathrm{s}$ \\
Oxygen flow rate & $1.11 \sim 4.72 \mathrm{Nm}^{3} / \mathrm{s}$ \\
\hline
\end{tabular}

\section{$2 \cdot 3110 t$ 規模実験}

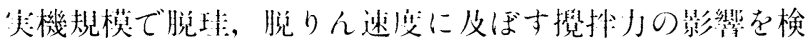

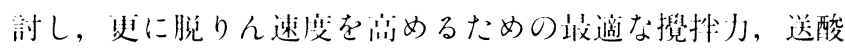
速度を求めるための尖験を行った。

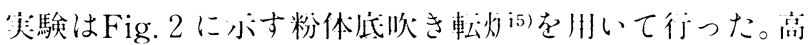

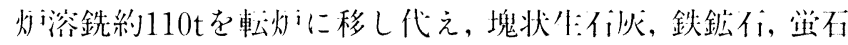
を所定星上小より添加し，ランスより酸系ガスを吹き付け

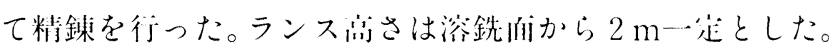

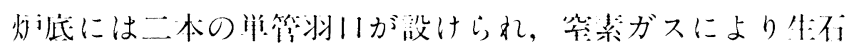

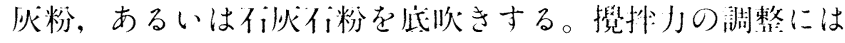

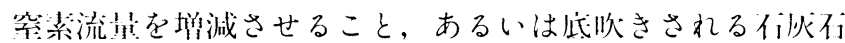

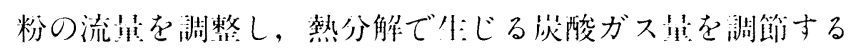
ことによって行った。

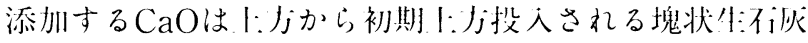

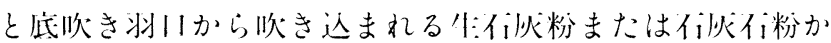
ら供給されるが,灯底から吹き远まれる $\mathrm{CaO}$ 制全は全 $\mathrm{CaO}$ 早の10〜30\%であった。また，酸然は初期に打投人される

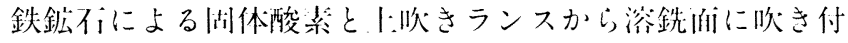
けられる父体酸少により供紷される。父体酸䒺ガスの制合 は全供給酸系Hし62１00\%であった。また，一部，父体酸 少吹き付けを行わず，酸系源として鉄鉣们のみを濑肘する

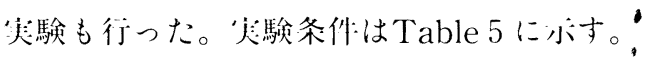

\section{$2 \cdot 4$ 反応モデル}

本報势で川いた浴銑脱りん文心解析モデルについては大

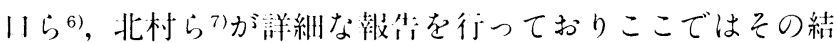
果について簡潔に述べる。

(1) 式の文心で衣される溶銑中のある成分Xの酸化速度 $n_{x}$ $(\mathrm{mol} / \mathrm{s})$ は $(2)$ 式で!j.えられる。 


$$
\begin{aligned}
\underline{X} & +n \underline{O}=\left(\mathrm{XO}_{\mathrm{n}}\right) \\
\mathrm{n}_{\mathrm{x}} & =\mathrm{k}_{\mathrm{m}} \mathrm{A}([\mathrm{X}]-[\mathrm{X}] *) \rho_{\mathrm{re}} /\left(100 \mathrm{M}_{\mathrm{X}}\right) \\
& =\mathrm{k}_{\mathrm{s}} \mathrm{A}\left(\left(\mathrm{XO}_{\mathrm{n}}\right) *-\left(\mathrm{XO}_{\mathrm{n}}\right)\right) \rho_{\mathrm{s}} /\left(100 \mathrm{M}_{\mathrm{XOn}}\right)
\end{aligned}
$$

ここで，界面でのみかけの衡'数 $\mathrm{E}_{\mathrm{x}}$ を川いると(2)式

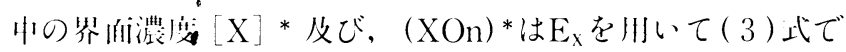

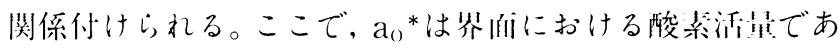
る。

$\mathrm{E}_{\mathrm{X}}=\left(\mathrm{XO}_{\mathrm{n}}\right) * /\left([\mathrm{X}] * \mathrm{a}_{0}{ }^{* n}\right)$

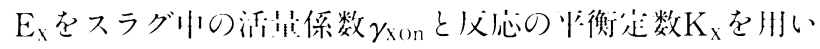

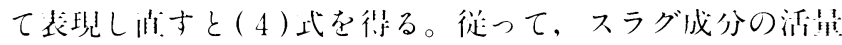

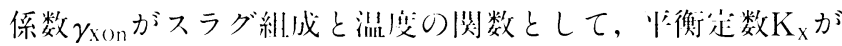

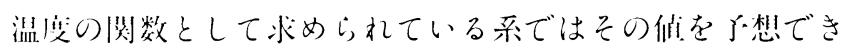
ることになる。

$$
\mathrm{E}_{\mathrm{x}}=100 \mathrm{Cf}_{\mathrm{x}} \mathrm{K}_{\mathrm{x}} /\left(\rho_{\mathrm{s}} \gamma \mathrm{x} \mathrm{O}_{\mathrm{n}}\right)
$$

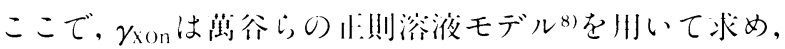

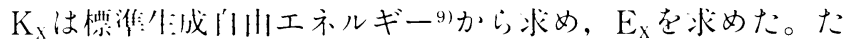

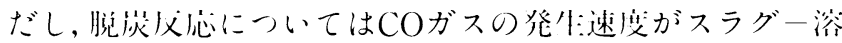
銑界血でのCO分に:の過飽利度 $\left(\mathrm{P}_{(\mathrm{C})}{ }^{*}-\mathrm{P}_{1}\right) / \mathrm{P}_{1}$ に比例すると

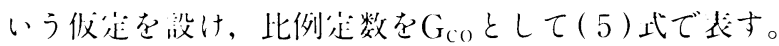

$$
\begin{aligned}
\mathrm{n}_{\mathrm{C}} & =\mathrm{k}_{\mathrm{m}} \mathrm{A}([\mathrm{C}]-[\mathrm{C}] *) \rho_{\rho_{\mathrm{c}}} /\left(100_{\mathrm{Mx}}\right) \\
& =\mathrm{G}_{\mathrm{CO}} \mathrm{A}\left(\mathrm{P}_{\mathrm{CO})} * / \mathrm{P}_{1}-1\right) \quad \ldots \ldots \ldots \ldots \ldots
\end{aligned}
$$

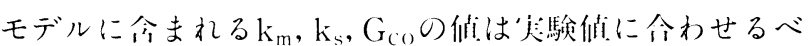

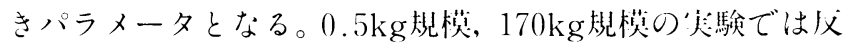
忍开イトはトップスラグー溶銧界面门及である。一j，是

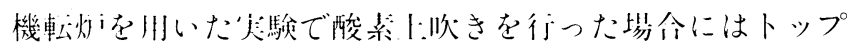
スラグー溶銧界面の及ならず，酸少ジェットが火呆を形成

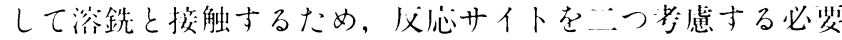

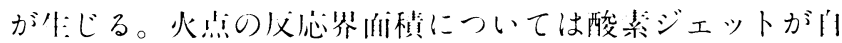

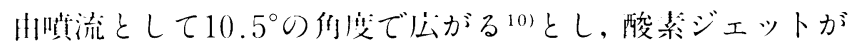

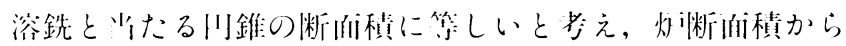

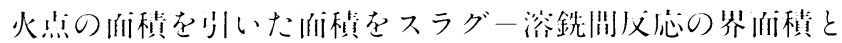

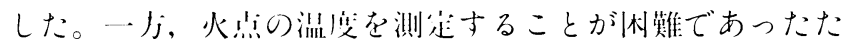

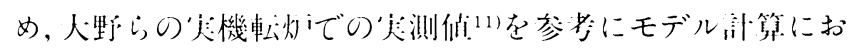
いては2350 $0^{\circ} \mathrm{C}$ 一是と似尘した。

\section{3. 実験結果}

\section{$3 \cdot 1 \quad 0.5 \mathrm{~kg}$ 規模実験結果}

Fig. 3 に $0.5 \mathrm{~kg}$ 规慔で行った浴銧脱りん时の溶銑組に成の経

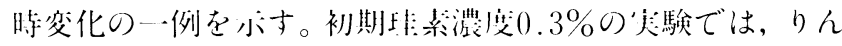

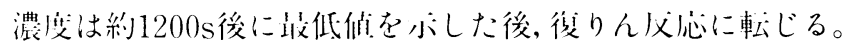

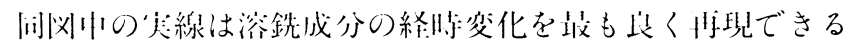

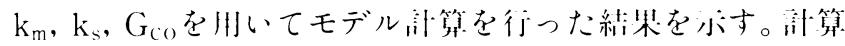
縤果は、脱りん文心の非じている1200後までの験絬果を

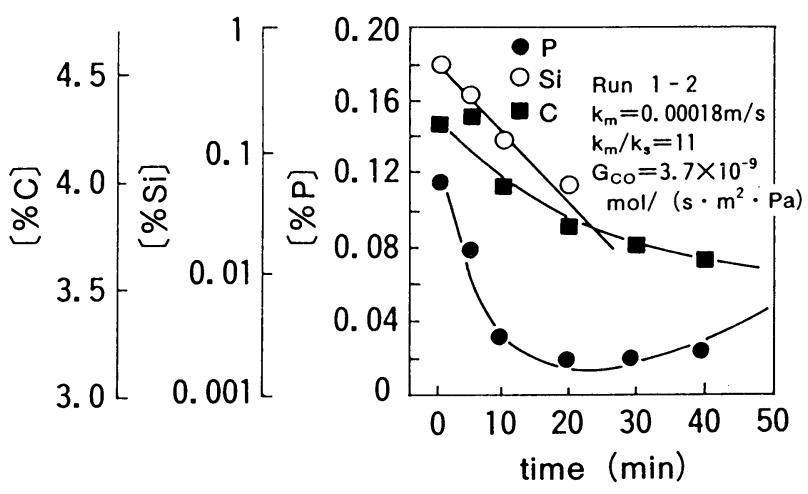

Fig. 3. Behavior of elements of hot metal. Solid lines indicate the calculated result $(0.5 \mathrm{~kg}$ scale experiment).

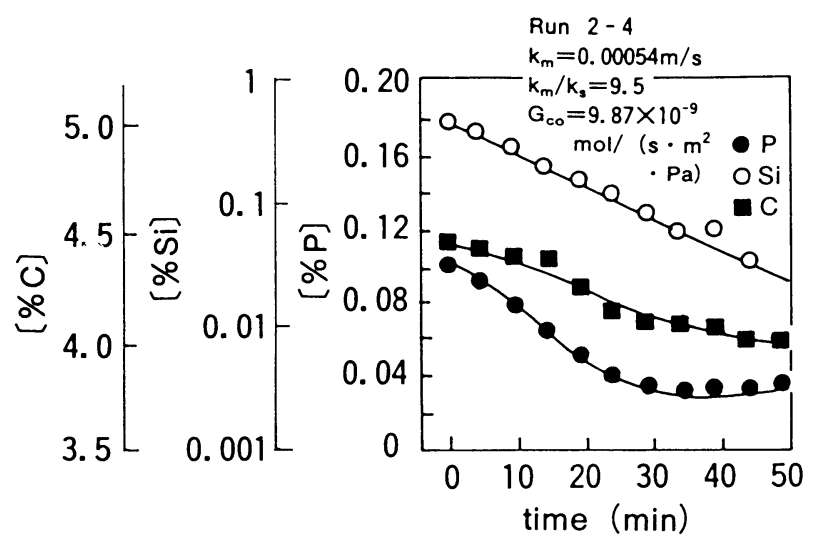

Fig. 4. Behavior of elements of hot metal. Solid lines indicate the calculated result $(170 \mathrm{~kg}$ scale experiment).

艮く再現している。しかし，1200s以降はスラグが冏体状を

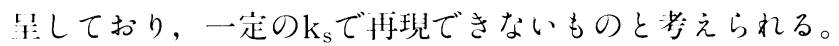

\section{$3 \cdot 2 \quad 170 \mathrm{~kg}$ 規模実験結果}

一例として初期珪素濃度を $0.3 \%$ とし日標塭基度を 2.0 と したTable 2 のRun No. 2-4 の溶銑成分の経時変化をFig. 4 に亦すが珪素濃度の対数值は時間に刘して直線となった。 最低のりん濃度は0.033\%であった。闰四中の垁線は反応モ デルによる計算結果を示すが計算值は实験值を良く再現し た。

\section{$3 \cdot 3110 t$ 規模実験結果}

Fig. 5 に酸素上吹きを実施した実験における溶銑組成の経 時変化の代表例を示す。四中の実線は反応解析モデルによ る㖕算結果を示しているが, 脱りん挙動を正確に再現出来 ていない。この理由は，上方より添加される塊状生石灰の 涬化速度の影響と考えられたため，精錬中の溶銑と同時に スラグを採取して分析し，生石灰の涬化の進行状況を調心゙ た。その結果をFig. 6 に示すが, 精錬時間の経過とともに生 不炏の涬化が進行していることが明らかとなった。そこで, この結果から，涬化率を時間の関数としてり光，以後のモ デル計算に使用することとした。計算結果を破線でFig. 5 中 に示しているが，生石灰の涬化速度を考慮することでりん 


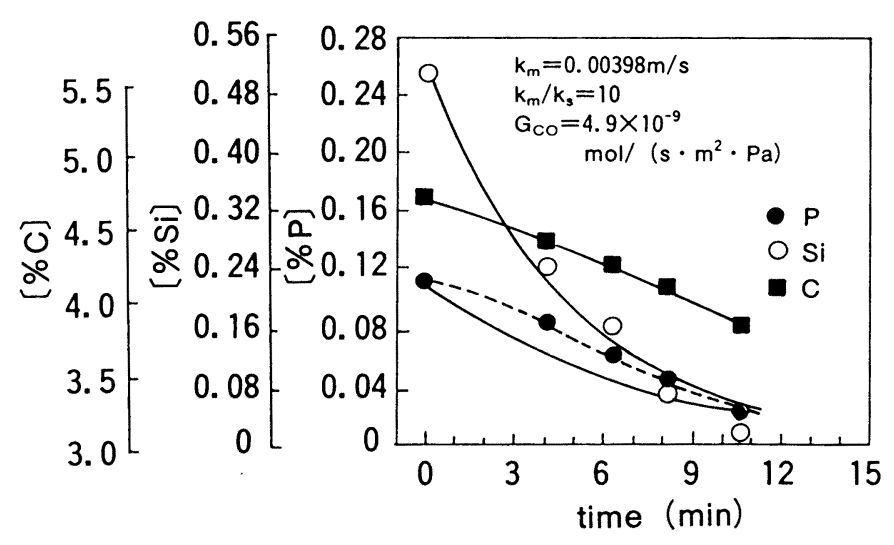

Fig. 5. Behavior of elements of hot metal with oxygen top blow. Solid and dotted lines indicate the calculated result (110t scale experiment)

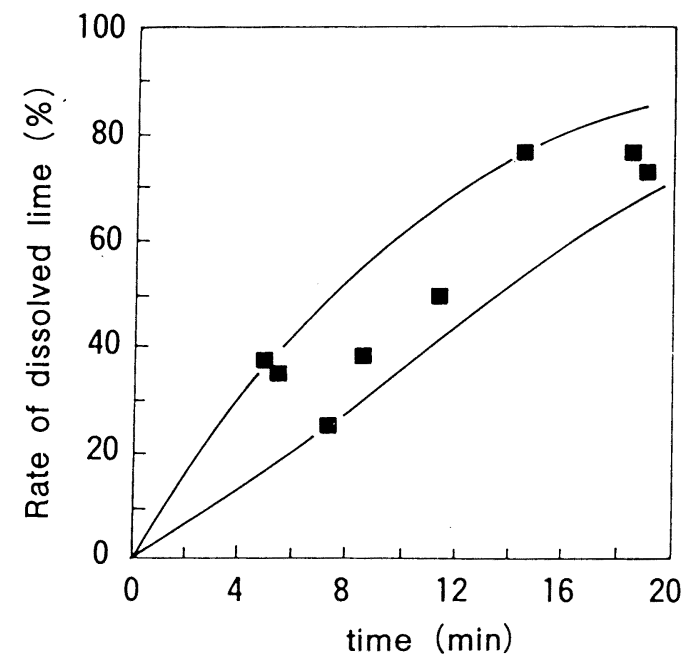

Fig. 6. Behavior of rate of lime dissolution with time during dephosphorization.

の挙動が良く再現できる。

\section{4. 考察}

\section{$4 \cdot 1$ スラグー溶銑間反応の律速段階}

酸素ガス上吹きを伴わない実験結果のみから得られたパ ラメータ, $\mathrm{k}_{\mathrm{m}}, \mathrm{k}_{\mathrm{s}}, \mathrm{G}_{\mathrm{co}}$ の值をTable 6 に示寸。 $\mathrm{k}_{\mathrm{m}}, \mathrm{k}_{\mathrm{s}}$ 沖装 置サイズ，㩭汼力によって変化している。一方， $\mathrm{k}_{\mathrm{m}} / \mathrm{k}_{\mathrm{s}}$ の值

Table 6. Parameters obtained from model calculations.

\begin{tabular}{ccccccc}
\hline Scale & $\begin{array}{c}\text { Aimed } \\
\text { basicity }\end{array}$ & $\begin{array}{c}\text { Initial } \\
{[\% \mathrm{Si})}\end{array}$ & $\begin{array}{c}\mathrm{k}_{\mathrm{m}} \times 10^{3} \\
(\mathrm{~m} / \mathrm{s})\end{array}$ & $\begin{array}{c}\mathrm{k}_{\mathrm{s}} \times 10^{3} \\
(\mathrm{~m} / \mathrm{s})\end{array}$ & $\begin{array}{c}\mathrm{k}_{\mathrm{m}} / \mathrm{k}_{\mathrm{s}} \\
(-)\end{array}$ & $\begin{array}{c}\mathrm{G}_{\mathrm{Co}} \times 10^{8} \\
\left(\mathrm{~mol} /\left(\mathrm{m}^{2} \cdot \mathrm{s} \cdot \mathrm{Pa}\right)\right)\end{array}$ \\
\hline \multirow{2}{*}{$0.5 \mathrm{~kg}$} & 1.93 & 0.00 & 0.12 & 0.011 & 11 & 0.37 \\
& 1.76 & 0.38 & 0.18 & 0.018 & 10 & 0.37 \\
\hline \multirow{2}{*}{$170 \mathrm{~kg}$} & 0.58 & 0.89 & 0.23 & 0.035 & 6.5 & 0.1 \\
& 2.00 & 0.30 & 0.54 & 0.057 & 9.5 & 0.99 \\
\hline \multirow{2}{*}{$110 \mathrm{t}$} & 1.70 & 0.51 & 1.09 & 0.109 & 10 & 0.49 \\
\hline
\end{tabular}

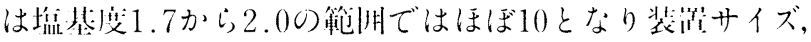

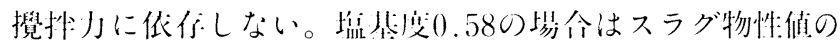

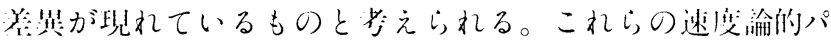
ラメータが求められたので，（６）式で衣される総括义灾速

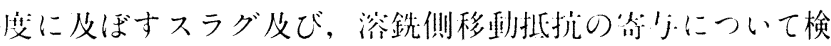

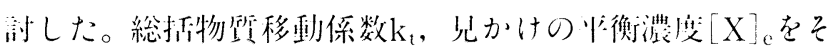

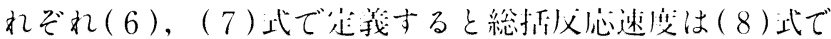
发される。

$$
\begin{aligned}
& 1 / \mathrm{k}_{\mathrm{t}}=1 / \mathrm{k}_{\mathrm{m}}+\mathrm{M}_{\mathrm{x} \cup \mathrm{n} \rho_{\mathrm{r}} \mathrm{c}} /\left(\mathrm{k}_{\mathrm{s}} \mathrm{E}_{\mathrm{x}} \mathrm{a}_{\mathrm{t}}{ }^{* \mathrm{n}} \mathrm{M}_{\mathrm{x}} \rho_{\mathrm{s}}\right) \\
& {[\mathrm{X}]_{\mathrm{e}}=\left(\mathrm{XO}_{\mathrm{n}}\right) /\left(\mathrm{E}_{\mathrm{x}} \mathrm{a}_{0}{ }^{* n}\right)} \\
& \mathrm{n}_{\mathrm{X}}=\mathrm{k}_{\mathrm{t}} \mathrm{A}\left([\mathrm{X}]-[\mathrm{X}]_{\mathrm{e}}\right) \rho_{\mathrm{l}} /\left(100 \mathrm{M}_{\mathrm{X}}\right)
\end{aligned}
$$

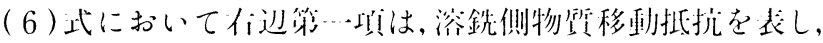

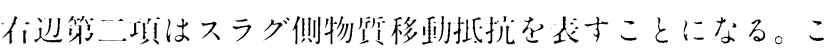
こではそれぞれの项を $\mathrm{R}_{\mathrm{m}} ， \mathrm{R}_{\mathrm{s}}$ と就すこととする。0.5 kg规

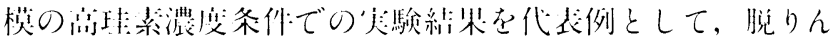

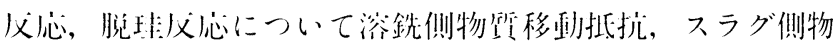

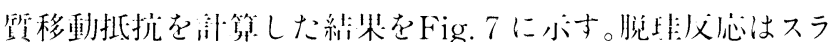

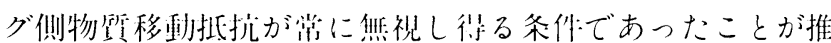

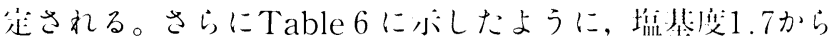

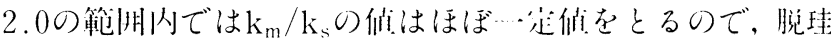

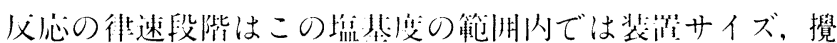

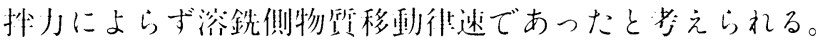

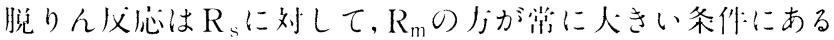
が，スラグ側の抵抗も常に無視できず，特に拉尛の酸化が

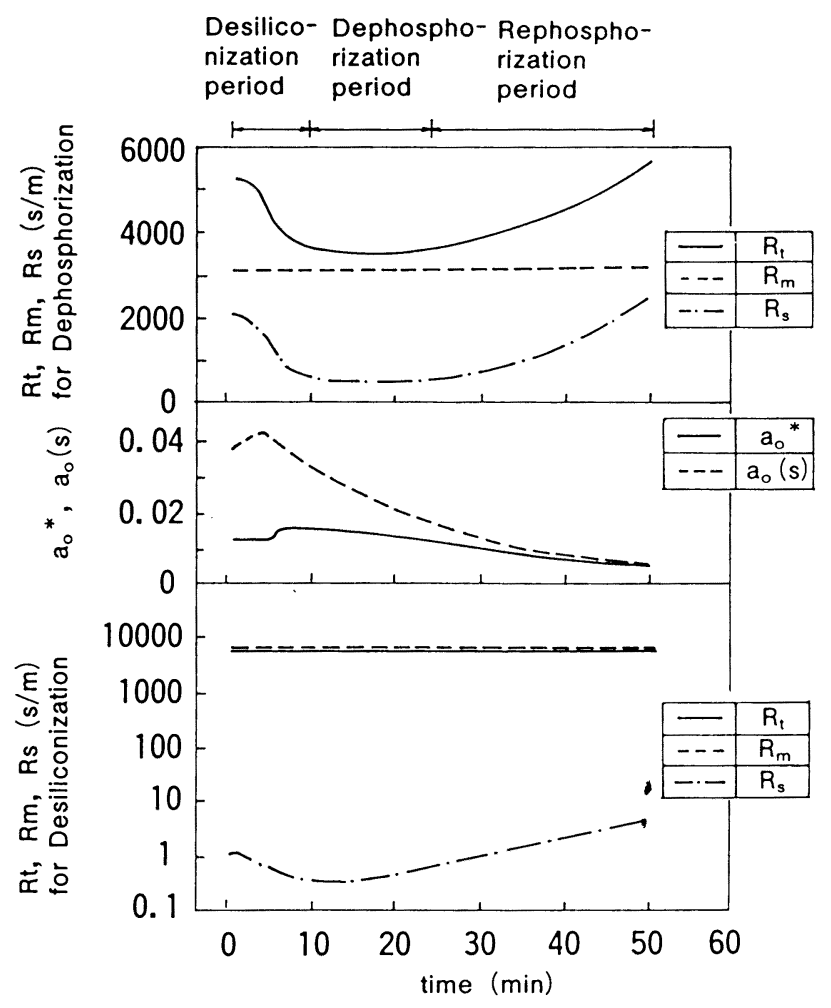

Fig. 7. Change in calculated resistances for dephosphorization and desiliconization and oxygen activity. 


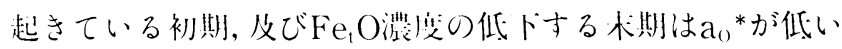
ためにスラグ側の抵扮が大きくなる倾修にある。さらに，

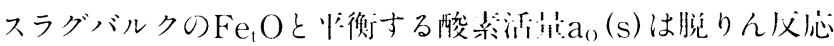

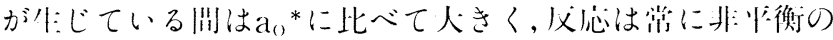
状態で進んでいることがあきらかである。

\section{$4 \cdot 2$ 溶銑側物質移動係数に及ぼす攪拌力の影響}

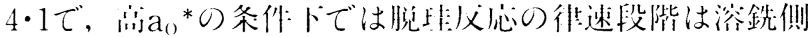

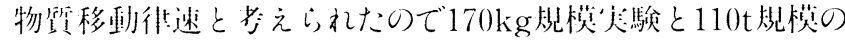

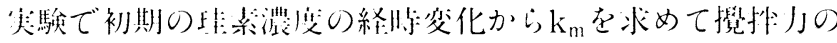
影響を新优した。

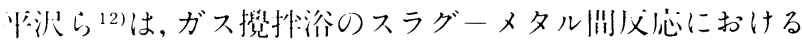
メタル側物質移動倸数について乱流理渝に基の゙き, 物質移

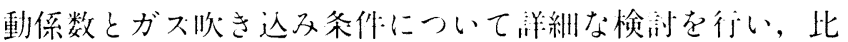

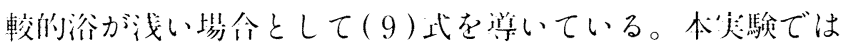

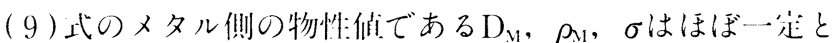

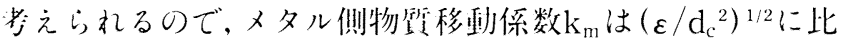
例することが期彷される。

$$
\mathrm{k}_{\mathrm{m}} \propto\left[\mathrm{D}_{\mathrm{M}} \rho_{\mathrm{M}} \varepsilon /\left(\sigma \mathrm{d}_{\mathrm{c}}{ }^{2}\right)\right]^{1 / 2}
$$

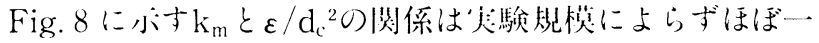

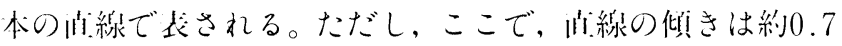
という做が得られた。

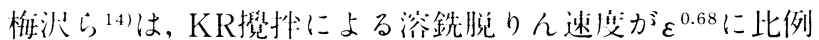

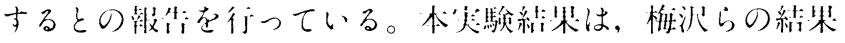

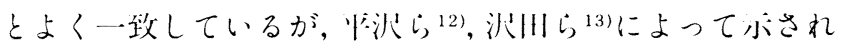

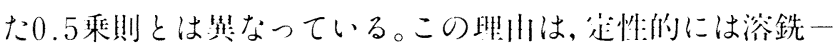
スラグ系必忠ではスラグ滴の浴銑への㥕き込及，あるいは 浴銑滴のスラグへの替き込及が多く，界面䅡增加の效果を

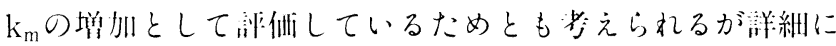
ついてはなお検测を紧する。

\section{$4 \cdot 3$ 送酸速度と底吹き擤拌の最適化}

スラグ巾のFeO湠度の苮い条作で, $\mathrm{k}_{\mathrm{m}} / \mathrm{k}_{\mathrm{s}}$ がほぼ一定に保

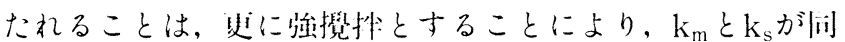
時に增加し，脱りん速废の们上が期街される。しかし底吹

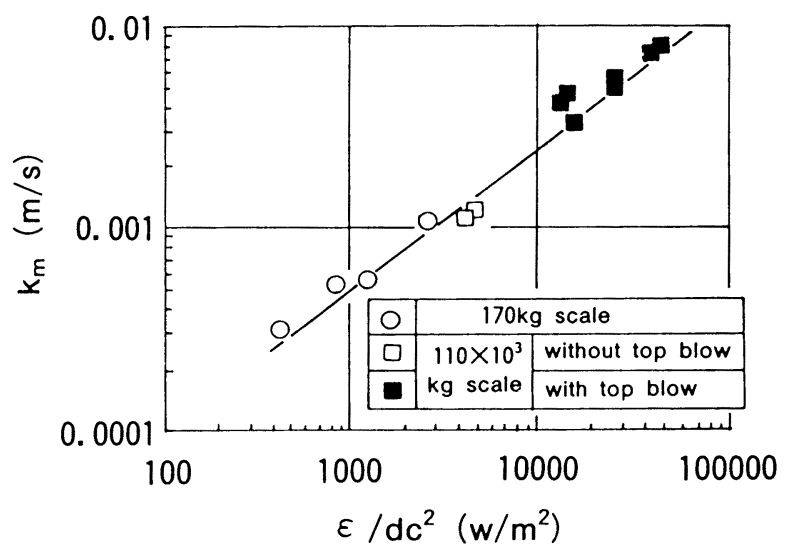

Fig. 8. Influence of stirring energy on mass transfer coefficient in hot metal.
き㩭汼力のみを增加することはスラグの $\mathrm{Fe}_{\mathrm{t}} \mathrm{O}$ の還元を促進 し, $\mathrm{Fe}_{\mathrm{t}} \mathrm{O}$ 浀度が確保出来なくなり， $\mathrm{a}_{0}$ *の低卜を招きスラグ 倒の抵抗を增加させ，脱りん速度を低卜させることが教元 られる。一) j, 底吹き㩭捧の弱い条件で酸素供給速度を増 加させても，りんの浴銑側物質移動が律速となり脱りん速 度は们、しないと考えられる。従って，年性们には底吹き

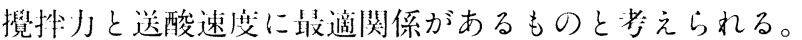

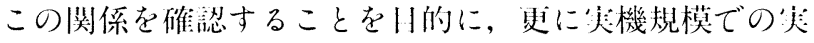
験を行った。ここで，マクロ的な脱りん速度を装す指標と してkp'を(10)式で尘義して送酸速度, 底吹き㩭汼小の影響 を訓健する。

$$
\mathrm{kp}^{\prime} \equiv \ln \left([\mathrm{P}]_{\mathrm{i}} /[\mathrm{P}]_{\mathrm{r}}\right) / \mathrm{t}_{\mathrm{f}}
$$

また, 総送酸速度 $\mathrm{V}_{\mathrm{O}_{2}}$ を(11) 式で定菚し酸枀供給速度を衣 すマクロ们な指標とする。

$$
\mathrm{V}_{\mathrm{O}_{2}} \equiv \mathrm{N}_{\mathrm{O}_{2}} / \mathrm{t}_{\mathrm{f}}
$$

kp’に及ぼす $\mathrm{V}_{\mathrm{O}_{2}}$, と’の影響をFig. 9 にホホすが，マクロ的に

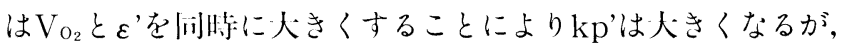
を’を $4 \mathrm{~kW} / \mathrm{t}$ 以に:に增加した埸合には $\mathrm{V}_{\mathrm{O}_{2}}$ の增加にともなって

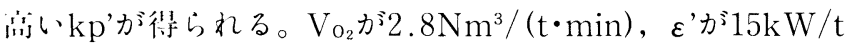

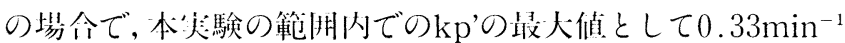
が得られ，脱りん時間は5.2minとなった。Fig. 9 中には厚 線で住忍モデルでア想される等脱りん速度線を小している が, 例吕ば $\mathrm{V}_{\mathrm{O}_{2}}=1 \mathrm{Nm}^{3} /(\mathrm{t} \cdot \mathrm{min}) て ゙ \varepsilon^{\prime}=20 \mathrm{~kW} / \mathrm{t}$ と低 $\mathrm{V}_{\mathrm{O}_{2}}$ が小 さな领域で做端にと支大きくした場合, $\varepsilon^{\prime}=4 \mathrm{~kW} / \mathrm{t} て ゙ \mathrm{~V}_{\mathrm{O}_{2}}=$ $3.0 \mathrm{Nm}^{3} /(\mathrm{t} \cdot \mathrm{min})$ と 'の小さな条件卜で板端に $\mathrm{V}_{\mathrm{O}_{2}}$ を大きく した塨令，行々スラグの過還元状態，りんの移動律速とな りどちらかを戦独で大きくしても kp’は大きくならないこと

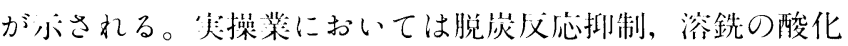

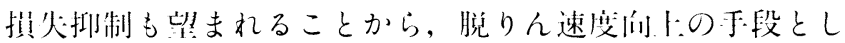
ては底吹き攪汼力を強化し，酸素供給速度を適目に保つこ

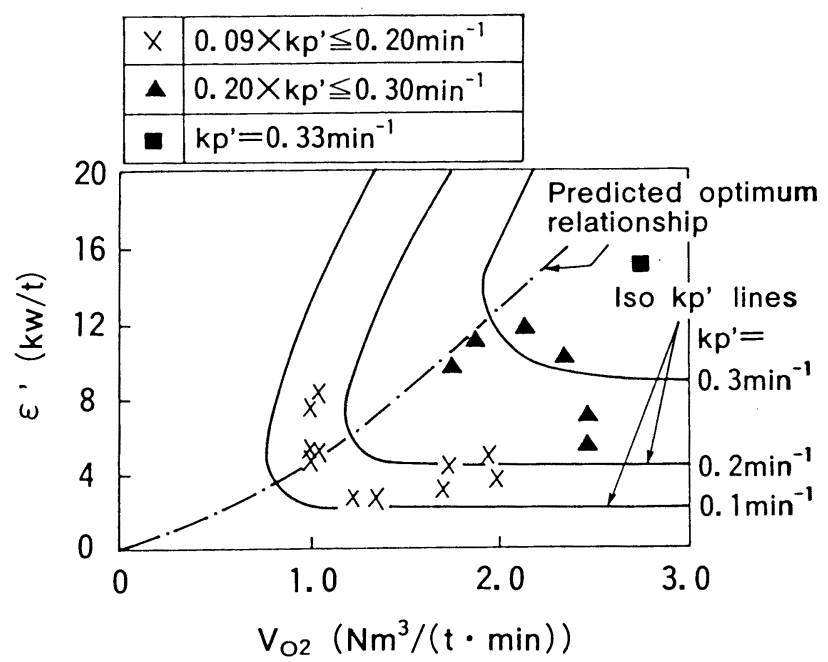

Fig. 9. Influence of stirring energy for molten bath and rate of supplied oxygen on dephosphorization rate. 
とが車罗であると考えられる。Fig. 9 には一点鎖線で $V_{\mathrm{O}_{2}}$ と

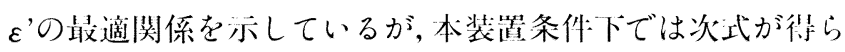
れた。

$$
\varepsilon^{\prime}=1.51 \mathrm{~V}_{\mathrm{O}_{2}}{ }^{2}+1.31 \mathrm{~V}_{\mathrm{O}_{2}}
$$

\section{5. 結論}

溶銑子備処理における高效摔な脱りん処理技術を確的す るため, 脱珪処理と脱りん処理を同時に行う力法について 父応速度論的検討を行った。

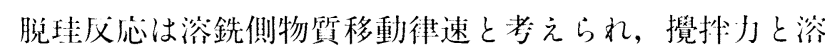
銑侧物睤移動係数との関係は $300 \mathrm{~kg}$ 規模, $110 \mathrm{t}$ 規模产験 $に\left(\varepsilon / \mathrm{d}_{\mathrm{c}}{ }^{2}\right)^{0.70}$ に比例して堌加した。本結果は梅沢らの結果と 发い一致をホしたが, 平沢ら, 決四らの0.5乗則とは一致し なかった。

脱りん文応はスラグおよび溶銑側物質移動の混合律速で あり, $\mathrm{k}_{\mathrm{m}} / \mathrm{k}_{\mathrm{s}}$ は嫶基度1.7〜2.0の範明で10前後の值となり装 置サイズ，覺抖力には依保しなかった。

攪汼力，酸素供給速度を適正な関係で增加することは脱 りん速度们けのトで有効な方法であることを溶銑脱りん笑 験とモデル解析から示し，本装置における最適関係として $\varepsilon^{\prime}=1.51 \mathrm{~V}_{\mathrm{O}_{2}}{ }^{2}+1.31 \mathrm{~V}_{\mathrm{O}_{2}}$ を得た。

\begin{tabular}{|c|c|}
\hline & 記 \\
\hline $\mathrm{A}$ & : 父忍界百積 $\left(\mathrm{m}^{2}\right)$ \\
\hline$a_{0}^{*}$ & ：スラグー溶銑界面での酸素活最 \\
\hline$a_{0}(s)$ & : スラグの $\mathrm{Fe}_{\mathrm{t}} \mathrm{O}$ と平衡する酸素活最 \\
\hline $\mathrm{C}$ & : スラグのモル密度 $\left(\mathrm{mol} / \mathrm{m}^{3}\right)$ \\
\hline$d_{c}$ & ：反応容器内径 $(m)$ \\
\hline $\mathrm{D}_{\mathrm{M}}$ & : メタル中成分の拡散係数 $\left(\mathrm{m}^{2} / \mathrm{s}\right)$ \\
\hline $\mathrm{E}_{\mathrm{x}}$ & ：みかけの平衡定数 \\
\hline$f_{x}$ & : 溶銑中X成分の活量係数 \\
\hline $\mathrm{G}_{\mathrm{CO}}$ & : 脱岑反心速度定数 $\left(\mathrm{mol} /\left(\mathrm{s} \cdot \mathrm{cm}^{2} \cdot \mathrm{atm}\right)\right)$ \\
\hline $\mathrm{H}$ & : メタル浴の深さ $(\mathrm{m})$ \\
\hline $\mathrm{K}_{\mathrm{x}}$ & : (1) 式の反応の平衡定数 \\
\hline $\mathrm{k}_{\mathrm{t}}$ & ：総括物質移動係数 $(\mathrm{m} / \mathrm{s})$ \\
\hline $\mathrm{k}_{\mathrm{m}}$ & ：溶銑側物質移動係数 (m/s) \\
\hline $\mathrm{k}_{\mathrm{s}}$ & ：スラグ側物犋移動係数 (m/s) \\
\hline $\mathrm{kp}$ & : マクロ的な脱りん速度走数 $\left(\mathrm{min}^{-1}\right)$ \\
\hline $\mathrm{M}_{\mathrm{x}}$ & : Xの分子量 $(\mathrm{kg} / \mathrm{mol})$ \\
\hline
\end{tabular}

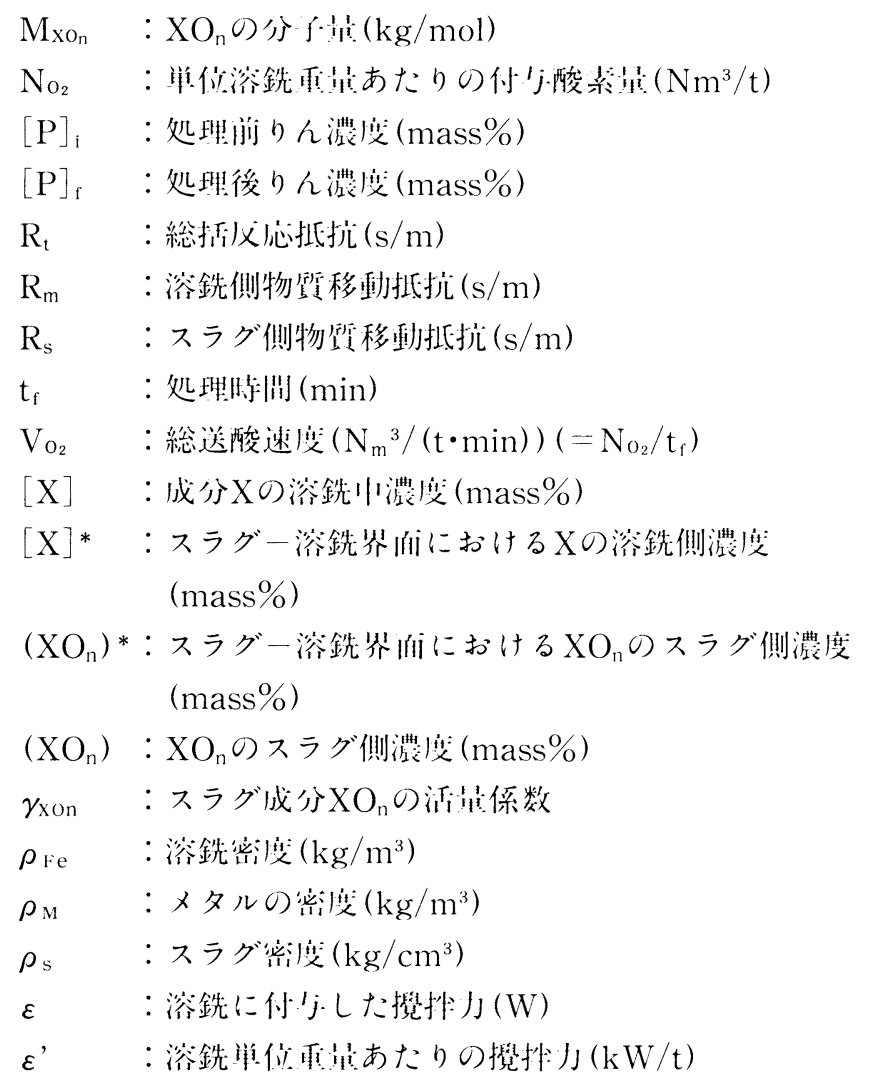

\section{文献}

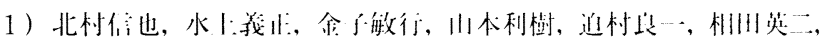
小野川修快：鉄と艇，76 (199()), p.1801

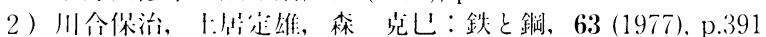

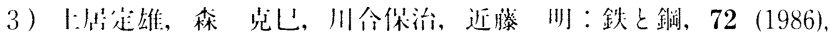
p. 1560

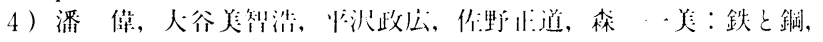
76 (1990), p. 1488

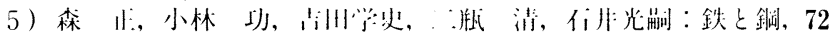
(1986), S171

6 ) S.Ohguchi, D.G.C.Robertson, Deo, P. Grieveson and J.H.E Jeffes : Ironmaking Steelmaking, 11 (1984), p.202

7 ) S.Kitamura, T.Kitamura, K.Shibata, Y. Mizukami, S.Muk awa and J.Nakagawa: ISIJ International, 31 (1991), p.1322

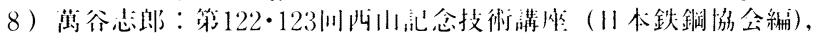
(1988), p.1

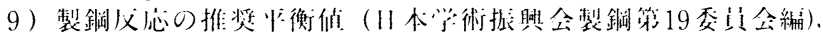
(1984), [1 们 I: 栄新间社]

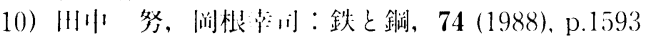

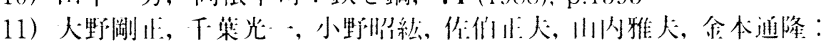
鉄飞䤱, 77 (1991), p.805

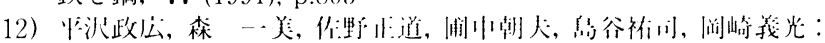
鉄と䥖，73 (1987), p.1343

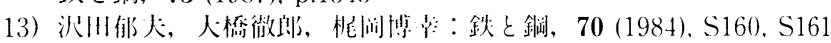

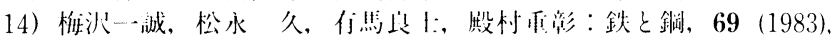
p.1810 